\title{
PRZYCZYNEK DO HISTORII POLSKO-JUGOSŁOWIAŃSKICH STOSUNKÓW KULTURALNYCH PO II WOJNIE ŚWIATOWEJ - DZIAŁALNOŚĆ WIKTORA BAZIELICHA NA POLU PROMOCJI KULTURY I JEGO PRACA TŁUMACZA ${ }^{1}$
}

W dziale rękopisów Biblioteki Jagiellońskiej w Krakowie znajduje się spuścizna Wiktora Bazielicha. Jest to dziesięć teczek nierównomiernej objętości zawierających rękopisy i maszynopisy. Większość materiałów stanowią listy, które Bazielich otrzymywał od swoich chorwackich, słoweńskich i serbskich korespondentów, korespondencja z Bośni i Hercegowiny oraz kopie listów, które Bazielich pisał w odpowiedzi, jak również materiały Towarzystwa Przyjaźni Polsko-Jugosłowiańskiej w Katowicach. Tam Bazielich mieszkał i pracował jako wysoki urzędnik na kolei, działał także w strukturach tegoż Towarzystwa. Biblioteka Jagiellońska weszła w posiadanie tej spuścizny w roku 1956, kilka lat po tym, jak Bazielich przestał utrzymywać stosunki ze swoimi przyjaciółmi z Jugosławii (1948). Być może sam Bazielich złożył ją jako depozyt w bibliotece uczelni, którą i sam ukończył, a po jego śmierci stała się częścią jej zbiorów.

Wiktor Bazielich urodził się 22 listopada 1892 roku w Starym Sączu, gdzie uczęszczał do szkoły podstawowej i gimnazjum. Później ukończył studia prawa na Uniwersytecie Jagiellońskim w Krakowie. Większość swego życia zawodowego spędził jako urzędnik Polskich Kolei Państwowych w Katowicach. Był żonaty i miał dzieci. Po II wojnie światowej działał w oddziale wojewódzkim Towarzystwa Przyjaźni Polsko-Jugosłowiańskiej w Katowicach. Zmarł 3 września 1963 roku, a pochowany został na cmentarzu miejskim w Krakowie. Poza pracą zawodową badał przeszłość swego rodzinnego miasta i jego okolic - opublikował ponad dziesięć artykułów na ten temat, a po jego śmierci wydano także dwie książki: Historie Starosądeckie (Wydawnictwo Literackie, Kraków 1965) i Starosądeckie domy rynkowe i ich dawniejsi właściciele (Sądecka Oficyna Wydawnicza, Nowy Sącz 1996). Jako zasłużonemu badaczowi historii Starego Sącza obywatele tego miasta nazwali jego imieniem bibliotekę miejską i jedną

${ }^{1}$ Moje badania w Krakowie mogłem prowadzić dzięki bilateralnej umowie o współpracy i wymianie pomiędzy Uniwersytetem w Zagrzebiu a Uniwersytetem Jagiellońskim w Krakowie. Dziękuję dr. Sebastianowi Grudniowi z Biblioteki Jagiellońskiej, który zwrócił moją uwagę na tę obszerną korespondencję, jak również prof. dr. Zdzisławowi Pietrzykowi, który umożliwił mi skopiowanie części spuścizny. 
$\mathrm{z}$ ulic ${ }^{2}$. Jednak jego bogata spuścizna nie została do tej pory w pełni zwaloryzowana ani wykorzystana $\mathrm{w}$ wystarczającej mierze.

Lista osób, z którymi Bazielich korespondował, jest naprawdę długa, a ponadto zawiera cały szereg nazwisk, od mniej znanych i dziś już niemal zapomnianych chorwackich pisarzy i pisarek, takich jak Marin Bego czy Ante Dukić, do wielkich nazwisk: Miroslava Krležy, Milana Begovicia, Ivany Brlić-Mažuranić czy Julija Benešicia i Frana Ilešicia. Korespondował on również z literatami z Serbii, Bośni i Hercegowiny, a czasami także ze słoweńskimi pisarzami i ludźmi kultury, np. z Đorđem Živanoviciem, Veljkom Petroviciem, Hamzom Humo, Isakom Samokovlija i innymi.

W jednym artykule opisałem niedawno wysiłki Bazielicha podjęte na polu promocji kultury chorwackiej i generalnie - jugosłowiańskiej w Polsce międzywojennej ${ }^{3}$. Znany chorwacki promotor kultury polskiej, polonofil i dyplomata jugosłowiański w Polsce w tym okresie Julije Benešić, nazwał Bazielicha „naszym zapalonym przyjacielem” („oduševljenim našim prijateljem”), który wiele lat tłumaczył chorwackie i serbskie nowele oraz wkładał wielki trud, aby je opublikować w polskich czasopismach ${ }^{4} . \mathrm{Na}$ początku lat trzydziestych XX wieku Bazielich wszedł w kontakt z Ivanem Esihom ${ }^{5}$. Po tym jak udało mu się z nim skontaktować, doszło do wymiany listów, a w jednym z nich Bazielich obszernie opisał swoją dotychczasową pracę - posłał swój życiorys i bibliografię tłumaczeń, w sumie siedem stron maszynopisu formatu A- $4^{6}$. W tym życiorysie Bazielich opisuje, jak samodzielnie nauczył się języka chorwackiego z książek, które odziedziczył po swym wuju, proboszczu z miejscowości Straconka koło Bielska-Białej. Ambitny młodzieniec Wiktor Bazielich zaczął je czytać i - przy pomocy słownika i podręcznika do samodzielnej nauki języka - powoli tłumaczyć niektóre $\mathrm{z}$ nich ${ }^{7}$. Szybko zrezygnował z tłumaczeń z czeskiego, gdyż biblioteka jego wuja nie obfitowała w dzieła czeskie, tylko w książki z terenów jugosłowiańskich. Przerzucił

2 Powiatowa i Miejsko-Gminna Biblioteka Publiczna w Starym Sączu, http://www.bib.stary.sacz.pl /?id=38922\&location=f\&msg=1\&lang_id=PL (15 XI 2010).

${ }^{3}$ D. Agičić, Wiktor Bazielich i njegovi hrvatski korespondenti. Prilog poznavanju hrvatsko-poljskih književnih i kulturnih veza u dvadesetom stoljeću, „Historijski zbornik”, LXII (2009), br. 1, 137-162.

${ }^{4}$ J. Benešić, Jugoslavenski pisci u poljskom prijevodu, Rad JAZU, knjiga 390, Zagreb 1981, s. 551 (pierwotnie opublikowane w gazecie „Obzor” 5 stycznia 1931 r.).

${ }^{5}$ Ivan Esih (1898-1966), profesor gimnazjalny, leksykograf, tłumacz i publicysta; pracował jako bibliotekarz i archiwista, a potem współpracownik naukowy Instytutu Literatury (Institut za književnost) JAZU. W okresie międzywojennym wyróżnił się jako tłumacz z wielu języków, promotor współpracy Chorwatów z innymi narodami słowiańskimi, szczególnie Czechami, Słowakami, Polakami i Bułgarami.

${ }_{6}^{6}$ BUJ Kraków, Spuścizna W. Bazielicha (dalej: SpWB) - rkps 48/56, Kopia listu W. Bazielicha Ivanu Esihu, Katowice, 7 II 1931. Ta notatka biograficzna istnieje w kilku wariantach, w korespondencji z innymi osobami, np. Julije Benešiciem. Najwyraźniej Bazielich na początku swych związków pragnął szczegółowo poinformować swych nowych przyjaciół o sobie i swojej pracy literackiej oraz przekładowej. $\mathrm{W}$ całości notatka została opublikowana w oryginale i w tłumaczeniu na chorwacki w moim tekście o Bazielichu w „Historijski zbornik”.

7 Pierwsze tłumaczenia z czeskiego wysyłał podpisane nazwiskiem swojego wuja, prawdopodobnie pragnąc się przedstawić znanym nazwiskiem. Jedna z nowel czeskiego pisarza i promotora stosunków polsko-czeskich Edvarda Jelinka (1855-1897) została wydrukowana w „Kurierze Lwowskim”. 
się na samodzielną naukę i tłumaczenie autorów chorwackich i serbskich. Włożył $\mathrm{w}$ to wiele pracy, pisał listy do autorów, a swoich korespondentów prosił o pomoc w lepszym zrozumieniu pewnych fragmentów tekstów, które tłumaczył, jak również o to, by mu napisali, gdzie popełnia błędy w języku chorwackim itp. Bardzo chciał pokazać swój wkład na polu chorwacko-polskiego zbliżenia oraz starał się wywrzeć na adresatach jak najlepsze wrażenie.

Korespondencja Bazielicha z Chorwatami i pozostałymi osobami z ówczesnej Jugosławii, w większości z pisarzami i ludźmi kultury, ma swe początki pod koniec lat dwudziestych XX w., a trwała aż do początku II wojny światowej. W trudnych latach wojny została przerwana, lecz po jej zakończeniu Bazielich próbował odnowić te kontakty. Jego powojenne listy pełne są ciepła i troski o starych przyjaciół, a reakcje na otrzymane odpowiedzi tryskają radością i zadowoleniem z wiadomości, że dana osoba przeżyła okropności wojny.

Z materiałów zachowanych w spuściźnie Bazielicha jasno wynika, że pieniądze nie były dla niego zupełnie bez znaczenia, szczególnie dlatego, że miał na utrzymaniu rodzinę, a uważał również, że jego trud i praca powinny być godziwie wynagrodzone, gdyż zabierały mu wiele wolnego czasu. W jego dorobku można natrafić na wiele listów, które wysyłał do różnych wydawców i redakcji czasopism. Rozpytuje się w nich o swoje honorarium, wspomina, że traci cierpliwość, czekając na wypłatę i tak przecież niewielkich sum. Z całej korespondencji można odnieść wrażenie, że Bazielich był osobą uczciwą, która jednak na najrozmaitsze sposoby starała się przejść przez trudy życia i osiągnąć swoje cele, pisząc bez skrępowania do największych twórców, pisarzy lub naukowców oraz do wysokich rangą dyplomatów. Zawsze jednak starał się, aby jego „przyjaciele”, jak często nazywał ludzi, z którymi korespondował, byli również finansowo wynagrodzeni.

Wiktor Bazielich najwyraźniej nie miał jakiejś szczególnie wyrobionej opcji ideologicznej czy też skrupułów związanych z polityką. W czasie wojny pisał na przykład do ambasady Niezależnego Państwa Chorwackiego w Berlinie, oferując swe usługi w tłumaczeniu książki Mile Budaka Ognjišta ${ }^{8}$. Mile Budak był jednym ze współzałożycieli i przywódców ruchu ustaszy, ideologiem tego ruchu i ministrem w rządzie Ante Pavelicia. Po wojnie w 1945 roku został oskarżony o zbrodnie wojenne i stracony. $\mathrm{Z}$ drugiej strony, największą powojenną pracą Wiktora Bazielicha było tłumaczenie dziennika Vladimira Nazora $Z$ partyzantami (S partizanima). Vladimir Nazor był jednym $z$ największych pisarzy i poetów chorwackich pierwszej połowy dwudziestego wieku. W czasach II wojny światowej opuścił Zagrzeb i przyłączył się do oddziałów partyzantki Josipa Broza Tity. Jako osoba powszechnie znana został pierwszym przewodniczącym parlamentu chorwackiego (Sabor NR Hrvatske). Zmarł w 1949 roku.

${ }^{8}$ BUJ Kraków, SpWB - rkps 52/56, Poslanstvo NDH - W. Bazielichu, Berlin, 14 IV 1942 i kilka innych listów w związku z tłumaczeniem i publikacją powieści M. Budaka. Z Budakiem Bazielich usiłował się skontaktować jeszcze w 1931 roku. W spuściźnie zachowana jest autobiografia Mile Budaka z początku tegoż roku. 
Dziennik $Z$ partyzantami Nazora miał być pierwszą książką tłumaczoną z języka chorwackiego, wydaną po wojnie w Polsce. W związku z pracą nad przekładem Bazielich wymieniał listy z różnymi przedstawicielami jugosłowiańskiej ambasady w Warszawie, jak również z polskimi wydawnictwami, którym oferował tłumaczenie. W końcu udało mu się znaleźć wydawcę - warszawską oficynę wydawniczą „Książka”. Jednakże po tym, jak książka Nazora była przetłumaczona, złożona do druku, przeprowadzona była korekta i jak książka została nawet wydrukowana, doszło do zerwania polsko-jugosłowiańskich stosunków politycznych w związku z Rezolucją Kominformu z czerwca 1948 r. wykluczającą Komunistyczną Partię Jugosławii z tego gremium (Biura Informacyjnego Partii Komunistycznych) i cały nakład książki został zniszczony.

W tym artykule pragnę przedstawić właśnie powojenną aktywność Wiktora Bazielicha związaną przede wszystkim z pracą nad tłumaczeniem dziennika V. Nazora i dać przegląd jugosłowiańskich kontaktów Bazielicha z tego okresu.

Bazielich bardzo wcześnie wznowił swą projugosłowiańską działalność. Ledwie skończyła się wojna, już w lecie 1945 zgłasza się do Towarzystwa Uniwersytetów Robotniczych w Warszawie, powołując się na ogłoszenie opublikowane w czasopiśmie „Odrodzenie” $\mathrm{nr} 35$, z propozycją napisania popularnej broszury o Jugosławii. Prosi, aby mu podać termin, objętość, ewentualnie potrzebę przysłania ilustracji oraz wysokość honorarium itp. ${ }^{9}$ Dwa dni później Bazielich pisze również do Wydziału Współpracy z Zagranicą Ministerstwa Kultury i Sztuki. W liście tym zgłasza swoją „gotowość do współpracy nad zapoznawaniem naszego społeczeństwa $z$ literaturą i sprawami kulturalnymi Jugosławii" ${ }^{10}$. Twierdzi, że przed wojną był jednym z pierwszych w Polsce, którzy pracowali na tej niwie: „Byłem czynny szczególnie jako tłumacz, a z prac ogłoszonych drukiem poza kilkunastu nowelami i kilkudziesięciu szkicami, felietonami i artykułami informacyjnymi, drukowanymi w prasie codziennej i w czasopismach, mam za sobą przekład tak trudnej powieści jak B. Stankovića ‘Nieczysta Krew’ („Nečista krv”) [...] oraz przekład tragedii M. Krležy 'Baronowa Lenbach' ('U agoniji') [...]”. Wspomina, że w czasach wojny dalej tłumaczył utwory różnych autorów chorwackich i od razu po jej skończeniu ma kilka gotowych prac.

We wrześniu 1945 Bazielich pisał do redakcji czasopisma „Odrodzenie” i proponował swój artykuł „Nieco o literaturze w 'niezależnej' Chorwacji”: „Skoro pisze się o literaturze francuskiej, radzieckiej, o Madziarach, uważam, że nie od rzeczy będzie podać coś i o naszych południowych pobratymcach, u których zawsze mieliśmy gorące 1945.

9 BUJ Kraków, SpWB - rkps 43/56, W. Bazielich - Zarząd Centralny TUR-u, Katowice, 8 sierpnia

${ }_{10}$ BUJ Kraków, SpWB - rkps 43/56, W. Bazielich - Ministerstwo Kultury i Sztuki, Wydział współpracy z zagranicą w Warszawie, Katowice, 10 VIII 1945. 
sympatie"11. Uważa, że byłoby też dobrze, jeśli ktoś napisze i o Serbach. Jako prawdziwy słowianofil, Bazielich uważał, że najpoważniejszy tygodnik społeczno-literacki powinien znaleźć miejsce dla spraw słowiańskich. Nie dostawszy żadnej odpowiedzi na swe propozycje, pisał miesiąc później i pytał, czy artykuł będzie drukowany ${ }^{12}$. Ten sam artykuł pod koniec listopada Bazielich przesłał do "Tygodnika Powszechnego" ${ }^{13}$. Właśnie wtedy, dwa dni po przesłaniu artykułu do nowego czasopisma dostał negatywną odpowiedź „Odrodzenia” 14 , a potem taka sama odpowiedź nadeszła i od redaktora „Tygodnika Powszechnego”, który pisał, że artykuł „nie odpowiada wymaganiom przyjętym w tym czasopiśmie oraz że jest dla ich czytelników zbyt ogólny ${ }^{15}$.

Bazielich nie zniechęcił się jednak negatywnymi reakcjami - już kilka dni po otrzymaniu drugiej negatywnej odpowiedzi przesyła swój tekst do następnego czasopisma - „Życia Literackiego” w Poznaniu, wykorzystując te same motywy o sympatiach południowych Słowian („pobratymców”) wobec Polaków ${ }^{16}$.

Najwyraźniej artykuł w tym czasopiśmie został opublikowany, gdyż kilka miesięcy później Bazielich otrzymał prośbę od sekretarza redakcji „Życie Słowiańskiego” (powołując się na opinię redaktora Henryka Batowskiego) o przesłanie podobnego tekstu jak ten o literaturze chorwackiej opublikowany $\mathrm{w}$ „Życiu Literackim” ${ }^{17}$. Bazielich chętnie przyjął tę propozycję i obiecał, że za kilka dni postara się przesłać „zmieniony nieco i uzupełniony artykuł o literaturze w 'niezawistej' Chorwacji'. Tydzień później posłał obiecany tekst ${ }^{18}$, a potem przesłał do „Życia Słowiańskiego” krótki tekst (notatkę) „Szkody wojenne muzeów i bibliotek w Serbii”"19.

Kilka miesięcy później Bazielich doczekał się pewnej satysfakcji, jeśli chodzi o ten artykuł. Redaktor Polskiego Radia Jakub Kołodziej napisał do niego, chwaląc tekst: „Doskonale Pan to ujął; chociaż temat bardzo śliski, wywiązał się Pan

11 BUJ Kraków, SpWB - rkps 43/56, W. Bazielich - Redakcja „Odrodzenia” w Krakowie, Katowice, 21 IX 1945.

12 BUJ Kraków, SpWB - rkps 43/56, W. Bazielich - Redakcja „Odrodzenia” w Krakowie, Katowice, 29 X 1945. W tym liście zaznaczył, że jest członkiem ZZLP.

${ }^{13}$ BUJ Kraków, SpWB - rkps 43/56, W. Bazielich - Redakcja „Tygodnika Powszechnego” w Krakowie, Katowice, 27 XI 1945. W liście tym powołał się też na to, że Polacy zawsze mieli „serdecznie sympatii” u swych „południwych pobratymcach”.

${ }_{14}$ BUJ Kraków, SpWB - rkps 43/56, Redakcja „Odrodzenie” w Krakowie - W. Bazielich, Kraków, 29 XI 1945.

${ }_{15}$ BUJ Kraków, SpWB - rkps 43/56, [Redakcja „Tygodnika Powszechnego”, podpis nieczytelny] W. Bazielich, [Kraków, 1 XII 1945 i 4 XII 1945].

16 BUJ Kraków, SpWB - rkps 43/56, W. Bazielich - Redakcja „Życia Literackiego” w Poznaniu, Katowice, 6 XII 1945.

${ }_{17}$ BUJ Kraków, SpWB - rkps 43/56, Redakcja „Życia Słowiańskiego” Warszawa-Kraków - W. Bazielich, Kraków, 24 IV 1946.

18 BUJ Kraków, SpWB - rkps 43/56, W. Bazielich - Redakcja „Życia Słowiańskiego” Warszawa-Kraków, Katowice, 2 V 1946 / 7 V 1946.

19 BUJ Kraków, SpWB - rkps 43/56, W. Bazielich - Redakcja „Życia Słowiańskiego” Warszawa-Kraków, Katowice, 12 V 1946. 
wyśmienicie"20. Obiecywał Bazielichowi przesłać książkę Filipa Lukasa, prezesa Macierzy Chorwackiej, przyjaciela Polski, „który właśnie pisał książkę o pochodzieniu Gotijskim Chorwatów".

Po wojnie Bazielich był członkiem Związku Zawodowego Literatów Polskich w Oddziale Śląskim w Katowicach. Interesował się też historią rodzinnego miasta - Starego Sącza, ale i historią regionu, w którym od wielu lat zamieszkiwał, tzn. Śląska. Zamawiał książki, czytał, a potem pisał. Planował udostępnić książki ze swojej prywatnej biblioteki - około 400 tomów różnych autorów jugosłowiańskich - członkom Towarzystwa Przyjaźni Polsko-Jugosłowiańskiej w Katowicach, „gdy tylko otrzymamy lokal”21.

Jak wielu innych współpracowników krakowskiego tygodnika „Odrodzenie” i Bazielich dostał w październiku 1946 pytanie w formie ankiety na temat bieżących prac polskich uczonych i pisarzy. Szybko odpowiedział, że zainteresowania jego idą w dwóch kierunkach: „1) historii jednego z najstarszych polskich miast, mego rodzinnego miasta Starego Sącza wraz z klasztorem klarysek, do którego przez 5 wieków należał, tudzież 2) stosunków polsko-jugosłowiańskich i literatury Chorwatów i Serbów"22. Z tej drugiej dziedziny miał wtedy - jak pisze - większą część tekstu „osobnej broszury lub nawet książki” o stosunkach politycznych polsko-jugosłowiańskich w przeszłości, przekład dziennika Vladimira Nazora $Z$ partyzantami oraz niedużej powieści Hamzy Huma Grozdanin kikot (Chichot Winoszy) oraz parę tłumaczeń dokończonych jeszcze w czasach przedwojennych: Dziwne przygody szewczyka Wojtusia Ivany Brlić-Mažuranić („bardzo miła i mądrze napisana powieść dla 8-10-letnich dzieci”), zbiór aforyzmów Antoniego Dukicia Poglądy na życie iświat, kilka nowel Veljka Petrovicia i Vladimira Nazora oraz tragedię Miroslava Krležy Baronowa Lenbach i inne prace. Miał zamiar dokończyć już w czasach wojny zaczęte tłumaczenie noweli M. Krležy Diabelska wyspa oraz wydać ją razem z przekładem Prymicji Alojzego Ticzka, który miał już gotowy. Potem chciał przetłumaczyć parę nowel Vladimira Nazora oraz wydać je z już przetłumaczonymi opowiadaniami tegoż pisarza w osobnej książce. Ma też ochotę kontynuować pracę nad tłumaczeniem obszernego dzieła Branislava Nušicia Rok 1915 - ma już sporo tekstu przetłumaczonego, ale nie jest pewny, czy po przeżyciu okropności II wojny światowej temat ten jest dla Polaków jeszcze interesujący.

Bazielich był po prostu wielkim miłośnikiem Jugosławii i jej narodów, ich historii i kultury, i wszelkimi siłami starał się, aby ją promować w Polsce. Cieszył się z jugosłowiańskich świąt państwowych i brał udział w organizacji na przykład świętowania Dnia Republiki w 1946 roku. Uroczystą akademię, jaką zorganizował z tej okazji, opisywał jako „piękną" aczkolwiek przygotowaną w bardzo krótkim czasie, „a mimo to zdołaliśmy ją urządzić ku zadowoleniu słuchaczy" ${ }^{23}$. W jednym ze swoich listów

${ }^{20}$ BUJ Kraków, SpWB - rkps 43/56, Jakób Kołodziej - W. Bazielich, Warszawa, 16 IV 1946.

${ }^{21}$ BUJ Kraków, SpWB - rkps 43/56, W. Bazielich - Zdzisław Okuljar, Katowice, 22 IV 1946.

${ }^{22}$ BUJ Kraków, SpWB - rkps 43/56, W. Bazielich - Redakcja tygodnika „Odrodzenie”, Katowice, 2 XI 1946.

${ }^{23}$ BUJ Kraków, SpWB - rkps 43/56, W. Bazielich - [L. Kusovac, Warszawa], Katowice, 10 XII 1946. 
Bazielich skarżył się, że Zarząd Główny Towarzystwa Przyjaźni Polsko-Jugosłowiańskiej w Warszawie nie dostarczył żadnego materiału na tę uroczystość - „wprost sabotował nas i sabotuje nas dalej" - oraz że obawiał się, iż uroczystość w Katowicach się nie uda, ale „w ciągu dosłownie 10 dni we dwójkę z sekretarzem zdołaliśmy zmontować wcale miły wieczór. Ale co to czasu i zdrowia kosztowało!"24

Brał udział w towarzyszeniu delegacji pisarzy jugosłowiańskich (Desanka Maksimović, Isak Samokovlija, Vjekoslav Kaleb i Blaž Koneski), która była z wizytą w Polsce w końcu października 1947 roku $^{25}$. Był zapewne bardzo szczęśliwy, gdy na początku grudnia otrzymał pocztówkę z Belgradu podpisaną przez D. Maksimović, Koneskiego i Smokovlije i drugą z Zagrzebia od Kaleba. Odpowiedział również pozdrowieniami, prosząc, aby przysłali swoje teksty z opisem wrażeń z Polski, jeśli takie napiszą ${ }^{26}$. Informował Kaleba, że próbował opublikować tłumaczenie jednej z jego nowel w „Odrodzeniu”, ale tekst mu zwrócili, a także, że spróbuje go wydrukować gdzieś indziej ${ }^{27}$.

Do Bazielicha od czasu do czasu zwracali się także inni polscy promotorzy literatur jugosłowiańskich, prosząc go o pomoc lub „informacje w sprawie nabycia czy ewentualnie udostępnienia poezji czy prozy jugosłowiańskiej [...] również jakie są możliwości nabycia czasopism literackich" ${ }^{28}$. Czasami zwracali się o pomoc w przetłumaczeniu swojej korespondencji, tak jak przykładowo redakcja „Trybuny Robotniczej" w Katowicach ${ }^{29}$. Na listy takie Bazielich odpowiadał szybko, informując o trudnościach w znalezieniu książek, a szczególnie czasopism jugosłowiańskich. Według niego, najlepsza droga do nabycia tych publikacji prowadziła przez ambasadę jugosłowiańską w Warszawie, chociaż i tam było tego tak mało, że nie wiedzieli, ,jak i kogo tym materiałem obdzielić". Bazielich wyrażał gotowość udostępnienia swojej biblioteki we własnym domu ${ }^{30}$.

Od czasu do czasu do Bazielicha zwracano się z prośbą o teksty, jak na przykład redaktor naczelny tygodnika literacko-społecznego „Odra” Wilhelm Szewczyk, który w kwietniu 1947 prosił go o dalszą współpracę: „zwłaszcza zależałoby nam na stałej kronice kulturalnej Jugosławii”" ${ }^{\prime 1}$. Na odpowiedź nie trzeba było długo czekać - już dwa dni później Bazielich podziękował za zaproszenie do współpracy w „Odrze”

${ }^{24}$ BUJ Kraków, SpWB - rkps 43/56, W. Bazielich - [Jakub Kołodziej, Warszawa], Katowice, 31 XII 1946.

${ }^{25}$ BUJ Kraków, SpWB - rkps 44/56, W. Bazielich - [Đorđe Živanović], Katowice 2 XI 1947.

${ }^{26}$ BUJ Kraków, SpWB - rkps 44/56, W. Bazielich - Desanka Maksimović, Katowice 6 XII 1947; BUJ Kraków, SpWB - rkps 44/56, W. Bazielich - Isak Samokovlija, Katowice 6 XII 1947.

${ }^{27}$ BUJ Kraków, SpWB - rkps 44/56, W. Bazielich - Vjekoslav Kaleb, Katowice 6 XII 1947.

${ }_{28}$ BUJ Kraków, SpWB - rkps 43/56, Zdzisław Okuljar - W. Bazielich, Bielsko 15 IV 1946.

${ }^{29}$ BUJ Kraków, SpWB - rkps 44/56, Redakcja „Trybuny Robotniczej” - W. Bazielich, Katowice 21 XI 1947.

${ }^{30}$ BUJ Kraków, SpWB - rkps 43/56, W. Bazielich - Zdzisław Okuljar, Katowice 22 IV 1946. / Z pocztówki z 28 kwietnia wynika, że Okuljar miał zamiar korzystać z propozycji Bazielicha o korzystaniu z jego prywatnej biblioteki.

${ }^{31}$ BUJ Kraków, SpWB - rkps 43/56, Wilhelm Szewczyk - W. Bazielich, Katowice 21 IV 1947. 
i obiecywał „coś w rodzaju kroniki”32. Mógł wtedy powoływać się na to i w różnych miejscach prosić o prasę i publikacje jugosłowiańskie ${ }^{33}$.

Już w lecie 1945 Bazielich próbował ponownie nawiązać kontakt ze swoimi przedwojennymi korespondentami, ale nie miał odpowiedzi. „A tak pragnąłbym nawiązać stare nici z powrotem i wziąć na warsztat coś z najnowszych cennych rzeczy” - pisał i prosił Wydział Zagraniczny Ministerstwa Kultury i Sztuki o pomoc w tej sprawie ${ }^{34}$. W tej samej kwestii pisał do Mariana Jakubca, attaché w polskiej ambasadzie w Belgradzie. Prosił go „o łaskawe ułatwienie nawiązania z powrotem zerwanych przez wojnę kontaktów ze sferami literackimi Jugosławii” ${ }^{35}$. Nie wiedział, jaki był los jego przedwojennych znajomych, pisał do kilku z nich, ale żadnej odpowiedzi do końca września 1945 nie otrzymał.

Na początku października 1945 r. Bazielich pisał do Jerzego Pogonowskiego (adwokata w Krakowie, przedwojennego tłumacza i przyjaciela Benešicia), dziękując za pozdrowienia, które dostał od niego za pośrednictwem swego przyjaciela Kałkowskiego. „Jestem wzruszony i zaskoczony tym, że Pan Mecenas poprzez tyle klęsk i katastrof i lat zatrzymał w pamięci moją skromną osobę obok tak wybitnego człowieka jak Dr Benešić" - pisał i pytał o losy swych jugosłowiańskich przyjaciół oraz prosił Pogonowskiego o pomoc w ich odnalezieniu. Już wiedział, że zmarli Nikola Andrić i Fran Ilešič ${ }^{36}$. Pogonowski szybko mu odpowiedział, że nie ma na razie żadnej korespondencji „z ziem słowiańskich”37.

Bazielich jeszcze jesienią 1945 nawiązał kontakt z Labudem Kusovcem, attaché prasowym jugosłowiańskiej ambasady w Warszawie, oczekując od niego pomocy „dla nawiązania z powrotem stosunków z Jugosławią i dla dalszej współpracy”" Z jugosłowiańskim dyplomatą postępował bardzo ostrożnie, przepraszał, że być może przeszkadza i zabiera czas. Jednak równocześnie pokrótce opisywał swą przedwojenną działalność na niwie promocji polsko-jugosłowiańskich związków literackich jako sekretarza Towarzystwa Polsko-Jugosłowiańskiego i jako tłumacza różnych autorów,

32 BUJ Kraków, SpWB - rkps 43/56, W. Bazielich - Wilhelm Szewczyk, Katowice 23 IV 1947.

${ }^{33}$ BUJ Kraków, SpWB - rkps 43/56, W. Bazielich - Zarząd Główny Towarzystwa Przyjaźni Polsko-Jugosłowiańskiej, Katowice 7 V 1947. BUJ Kraków, SpWB - rkps 43/56, W. Bazielich - Zarząd Główny Towarzystwa Przyjaźni Polsko-Jugosłowiańskiej, Katowice 24 VII 1947.

${ }^{34}$ BUJ Kraków, SpWB - rkps 43/56, W. Bazielich - Ministerstwo Kultury i Sztuki, Wydział współpracy z zagranicą w Warszawie, Katowice, 10 VIII 1945.

${ }_{35}$ BUJ Kraków, SpWB - rkps 43/56, W. Bazielich - [Marian Jakubiec, Belgrad], Katowice, 25 IX 1945.

${ }^{36}$ BUJ Kraków, SpWB - rkps 43/56, W. Bazielich - [Dr Jerzy Pogonowski, Kraków], Katowice, $10 \times 1945$.

37 BUJ Kraków, SpWB - rkps 43/56, Jerzy Pogonowski - W. Bazielich, Kraków 14 X 1945.

${ }^{38}$ BUJ Kraków, SpWB - rkps 43/56, W. Bazielich - [Dr Jerzy Pogonowski, Kraków], Katowice 4 XI 1945. 
a podkreślał przede wszystkim swoje tłumaczenia Nečiste krvi Stankovicia i U agoniji Miroslava Krležy, które spotkały się z dobrym przyjęciem polskiej publiczności ${ }^{39}$. Skarżył się, że okoliczności wojenne i nazistowska okupacja w obu krajach naruszyły również związki kulturalne i dlatego w Polsce bardzo trudno o informacje o „bratnim nam narodzie ze Słowiańskiego Południa”, a brak tych wiadomości szczególnie odczuwalny był - według Bazielicha - na Śląsku. Uważał, że to wielka szkoda i że przerwane związki z Jugosławią powinno się odnowić: „Dziś, twierdzę, gdy zwyciężyliśmy niemiecki faszyzm, jest czas najwyższy, aby odnowić między innymi i związki literackie" ${ }^{\prime 40}$. Od dyplomaty jugosłowiańskiego, attaché prasowego, oczekiwał pomocy w odnowie starych i nawiązywaniu nowych kontaktów. Prosił go o jugosłowiańską prasę i czasopisma literackie, jak również książki, twierdząc, że artykuły z prasy jugosłowiańskiej, które był gotów tłumaczyć na polski z pewnością by „natrafiły na duże zainteresowanie naszych czytelników".

Na odpowiedź z ambasady nie musiał długo czekać - Kusovac odezwał się już po kilku dniach. Podkreślał swą wielką radość w związku z tym, że Bazielich zwracał się do niego w „pięknym języku serbskim” i że wyraża chęć pracy w celu zbliżenia „naszych dwóch braterskich narodów słowiańskich”. Wspominał, że dziesięć dni wcześniej był z ambasadorem Božom Ljumovićem w Katowicach i okazał żal, że nie był wcześniej poinformowany o tym przypadku, gdyż z pewnością odnalazłby Bazielicha i rozmawiał z nim o wszystkim, co go interesuje. Ponieważ przepadła okazja osobistego spotkania w Katowicach, Kusovac zaprosił Bazielicha na rozmowę do Warszawy ${ }^{41}$.

Z ambasady jugosłowiańskiej Bazielich zaczął wtedy dostawać gazety i czasopisma oraz broszury propagandowe. Dziękował za przesłane materiały, dalej prosząc o czasopisma literackie, przede wszystkim z Serbii, Chorwacji oraz Bośni i Hercegowiny ${ }^{42}$. Nie raz powtarzał tę swoją prośbę, podkreślając, że interesuje go „literatura piękna i sztuka”" Twierdził, że nadesłane gazety jugosłowiańskie „mało go interesują", ale dowiedział się z nich na przykład, że wojnę przeżyli jego znajomy literaci Veljko Petrović i Hamza Humo i od razu zabrał się do pisania do nich listów. Dowiedział się też, że żyje wielki poeta słoweński Oton Župančič oraz że polityk serbski Milan Popović jest oskarżony o współpracę z Węgrami i czetnikami Dražy Mihailovicia. Jeszcze na początku grudnia $1945 \mathrm{r}$. Bazielich nie miał żadnych wiadomości o swych chorwackich znajomych ${ }^{44}$.

Na wiosnę 1946 roku Bazielich kontynuuje poszukiwania przyjaciól jugosłowiańskich. Między innymi, pisze po serbsku do Veljka Petrovicia do Belgradu, szczęśliwy,

39 BUJ Kraków, SpWB - rkps 43/56, W. Bazielich - [L. Kusovac, Warszawa], Katowice 14 X 1945.

${ }^{40}$ BUJ Kraków, SpWB - rkps 43/56, W. Bazielich - [L. Kusovac, Warszawa], Katowice 14 X 1945.

${ }^{41}$ BUJ Kraków, SpWB - rkps 43/56, L. Kusovac, Ambasada Demokratske Federativne Jugoslavije u Varšavi - W. Bazielich, 26 X 1945.

${ }^{42}$ BUJ Kraków, SpWB - rkps 43/56, W. Bazielich - [L. Kusovac, Warszawa], Katowice 4 XII 1945.

${ }^{43}$ BUJ Kraków, SpWB - rkps 43/56, W. Bazielich - [L. Kusovac, Warszawa], Katowice 30 XII 1945.

${ }^{44}$ BUJ Kraków, SpWB - rkps 43/56, W. Bazielich - [Jerzy Pogonowski, Kraków], Katowice 9 XII 1945. 
że w jednym z numerów „Politiki” odnalazł jego nazwisko i dowiedział się, że Petrović przeżył wojnę. Choć Bazielich i Petrović nigdy się osobiście nie spotkali, byli w kontakcie listownym w czasie, gdy Bazielich tłumaczył nowele Petrovicia. Teraz Bazielich życzył mu wielu sukcesów i prosił o pomoc w odnowieniu starych kontaktów, to jest o to, aby Petrović posłał mu adresy pewnych osób i instytucji, które mógłby poprosić o czasopisma naukowe i kulturalne, brakujące mu w jego pracy literackiej. Szczególnie interesowały go adresy historyków i numizmatyków. Pytał też, jak wygląda sytuacja z Towarzystwem Polsko-Jugosłowiańskim. W tym samym liście Bazielich skarżył się na trudności w działaniu poczty pomiędzy Polską i Jugosławią, w związku z czym odpowiedzi od Petrovicia oczekiwał za pośrednictwem ambasady w Warszawie. Sam list przesłał przez delegata jakiejś komisji jugosłowiańskiej przebywającej w Polsce, który wracał do kraju, a Petroviciowi deklarował chęć pomocy w zdobywaniu materiałów, które by mu ewentualnie były potrzebne z Polski ${ }^{45}$. Pod koniec 1946 roku Bazielich przesłał redakcji „Dziennika Zachodniego” w Katowicach tłumaczenie noweli Petrovicia Ziemia, podkreślając, że byłby to „pierwszy większy utwór literacki jugosłowiańskiego autora drukowany u nas po wojnie, bowiem - jak dotąd - prócz paru wierszy nic jeszcze z literatury jugosłowiańskiej nie opublikowano"46.

Bazielich był mile zaskoczony, gdy jesienią 1946 roku dostał od Ante Dukicia jego książkę Zov Kvarnera. Od razu zabrał się do pisania obszernego listu, w którym opisywał swoje wcześniejsze bezskuteczne poszukiwania Dukicia, pisał, że wysłał mu kartkę pocztową, pytał Ivana Esiha o niego, że szukał jego imienia w gazetach i czasopismach chorwackich, które od czasu do czasu otrzymuje z ambasady jugosłowiańskiej - i wszystko to na próżno, gdyż nigdzie nie natrafił na jego ślad. Dlatego był prawie przekonany, że Dukicia nie ma już wśród żywych. Tym bardziej był szczęśliwy, gdy dotarła od niego książka: „Zaskoczył mnie Pan i ucieszył bardzo! Dziękuję Panu za książkę i Bogu dzięki, że Pan żyje!" "77 Dalej pisał o tym, że jest bardzo obciążony różnymi obowiązkami w pracy, aktywnościami w Towarzystwie Polsko-Jugosłowiańskim, ale także swoimi pracami literackimi i historycznymi, w związku z czym dość nieregularnie koresponduje z jugosłowiańskimi przyjaciółmi - do tego momentu nawiązał kontakt tylko z Ivanem Esihem. Prosił Dukicia o informacje o Božy Lovriciu i o śmierci Frana Ilešiča, jak również o nowe wydanie jego książki Pogledi na život i svijet - oferował, że może dopracować swoje tłumaczenie i postarać się znaleźć wydawcę.

W grudniu 1946 Bazielich korzystał z okazji wysokiego odznaczenia Julija Benešicia (,jakie Pan albo może już dostał, albo w najbliższym czasie otrzyma od naszego Rządu w uznaniu zasług dla naszej literatury przez dokonanie tylu świetnych z niej przekładów") i po raz trzeci po wojnie do niego pisał. Informował chorwackiego literata, że odznaczenie to rząd polski przyzna mu właśnie na jego wniosek, bo to właśnie on,

${ }^{45}$ BUJ Kraków, SpWB - rkps 43/56, W. Bazielich - [Veljko Petrović, Beograd], Katowice 8 IV 1946.

${ }^{46}$ BUJ Kraków, SpWB - rkps 43/56, W. Bazielich - Redakcja „Dziennika Zachodniego” w Katowicach, Katowice 25 VI 1946.

${ }^{47}$ BUJ Kraków, SpWB - rkps 43/56, W. Bazielich - [Ante Dukić, Zagrzeb], Katowice 1 XI 1946. 
Bazielich, złożył taką propozycję do Zarządu Głównego Towarzystwa Przyjaźni Polsko-Jugosłowiańskiej i Zarządu Głównego Zawodowego Związku Literatów Polskich ${ }^{48}$. $\mathrm{Na}$ list ten Benešić odpowiedział Bazielichowi kilka tygodni później. Pamiętał o nim („nieraz rozmawiałem $\mathrm{z}$ drem. Esihem o Panu”), ale nie otrzymał żadnych listów od niego. Pisał, że nie od razu zrozumiał gratulacje przesłane przez Bazielicha; gdy we wrześniu podczas pobytu polskiej państwowej delegacji w Zagrzebiu otrzymał złoty krzyż, nie wiedział, jakie to wysokie odznaczenie - teraz już wie ${ }^{49}$. Prosił go o „Życie słowiańskie" nr 7/8 oraz pisał o swojej pracy nad tematami polskimi.

Wiktor Bazielich wiele swojego wolnego czasu poświęcał promocji jugosłowiańskiej kultury. W drugiej połowie marca 1946 roku od Zarządu Obwodu Polskiego Związku Zachodniego (PZZ) w Katowicach dostał list z pytaniem, czy jest już dyspozycyjny, aby mógł regularnie uczestniczyć w pracy w Obwodzie i brać udział w posiedzeniach Zarządu Obwodu, czy też zrezygnuje z członkostwa ${ }^{50}$. Odpowiedział parę dni później, usprawiedliwiając się przed Zarządem Obwodu PZZ w Katowicach innymi obowiązkami, przede wszystkim pracą nad sprawami promocji literatury i kultury jugosłowiańskiej. Bazielich twierdził, że to właśnie on, „jako jedyny w Katowicach z czasów przedwojennych członek zarządu Towarzystwa Polsko-Jugosłowiańskiego doprowadził” razem z inż. Chomiakowem do zorganizowania „Towarzystwa Przyjaźni Polsko-Jugosłowiańskiej w Katowicach". Został wybrany na stanowisko sekretarza zarządu wojewódzkiego ${ }^{51}$. Dostał polecenie tegoż towarzystwa, aby napisał broszurę informacyjną o Jugosławii. Informował dalej, że właśnie u niego ambasada jugosłowiańska zamówiła tłumaczenie książki Vladimira Nazora $Z$ partyzantami, w związku z czym stara się szybko zakończyć ten przekład. Z drugiej strony, od Komitetu Słowiańskiego z Warszawy też ma zamówienia różnych tłumaczeń, a czasopismo „Życie Słowiańskie” „także domaga się mojej współpracy”. Jak bardzo Bazielich był zajęty sprawami jugosłowiańskimi świadczy też jego twierdzenie, że „ambasada jugosłowiańska życzy sobie szerszego opracowania i wydania drukiem mego odczytu o polsko-jugosłowiańskich stosunkach politycznych na przestrzeni wieków, wygłoszonego $27 \mathrm{bm}$. na inaugurację Tow. Przyjaźni Polsko-Jugosłowiańskiej w Katowicach”. W związku z tym, nie mając wystarczającej ilości wolnego czasu, Bazielich zrezygnował z członkostwa w Zarządzie Obwodu PZZ w Katowicach ${ }^{52}$.

Wiosną 1946 Bazielich pracował nad szerszą wersją referatu o stosunkach polsko-jugosłowiańskich, bo trzy miesiące później, pod koniec czerwca, przesłał ją swemu

${ }^{48}$ BUJ Kraków, SpWB - rkps 43/56, W. Bazielich - [Julije Benešić], Katowice 11 XII 1946. BUJ Kraków, SpWB - rkps 43/56, W. Bazielich - [Ivan Esih], Katowice 13 XII 1946.

${ }^{49}$ BUJ Kraków, SpWB - rkps 43/56, J. Benešić - W. Bazielich, Zagreb 8 I 1947.

${ }^{50}$ BUJ Kraków, SpWB - rkps 43/56, Zarząd Obwodu PZZ w Katowicach - W. Bazielich, Katowice 26 III 1946.

${ }^{51}$ BUJ Kraków, SpWB - rkps 43/56, W. Bazielich - Zarząd Obwodu PZZ w Katowicach, Katowice 30 III 1946.

${ }^{52}$ BUJ Kraków, SpWB - rkps 43/56, W. Bazielich - Zarząd Obwodu PZZ w Katowicach, Katowice 30 III 1946. 
dyrektorowi Edmundowi Odorkiewiczowi, posłowi Krajowej Rady Narodowej ${ }^{53}$. Jeszcze jesienią tegoż roku nie ukończył tej pracy, gdyż w odpowiedzi na ankietę „Odrodzenia” pisał, że tekst „jest już może $3 / 4$ gotowy, ale przy ograniczonych możliwościach pracy nad takim tematem w Katowicach, zwłaszcza z braku jugosłowiańskiej literatury historycznej, trudno dobrnąć do końca" ${ }^{54}$. O pomoc w dokończeniu tego tekstu, a szczególnie „o jakąkolwiek pomoc w wyświetleniu i przedstawieniu tych kwestii czy to przez przesłanie mi odpowiedniej literatury w formie pożyczki, czy zamiany, czy to przez sporządzenie wyciągów i odpisów, czy też wreszcie przez pisemne informacje, lub choćby tylko skontaktowanie mnie z jakim historykiem", prosił Bazielich Julija Benešicia na początku roku $1947^{55}$. Jednak prośba ta była bardzo skomplikowana i Benešić nie mógł jej spełnić.

W tym czasie Bazielich zintensyfikował swoją działalność w zakresie promocji stosunków polsko-jugosłowiańskich oraz tłumaczeniu z literatur południowosłowiańskich. W lipcu zwrócił się do redakcji tygodnika „Wieś” z propozycją opublikowania jego tekstu o Mihovilu Pavleku-Miškinie, „najwybitniejszym jugosłowiańskim, a specjalnie chorwackim literacie chłopskim, zamordowanym przez faszystowskich ustaszów" oraz przekładów czterech jego utworów ${ }^{56}$. Miesiąc potem pytał, jaki jest los jego tekstu oraz tłumaczeń ${ }^{57}$. Odpowiedziano mu pod koniec września, że w tygodniku tym opublikują trzy jego przekłady z utworów Miškiny ${ }^{58}$, ale to jednak nie zdarzyło się do połowy grudnia - prosił więc redakcję tygodnika o przyśpieszenie tej publikacji ${ }^{59}$. Jesienią 1947 ponownie zwrócił się do redakcji „Wsi”, proponując opublikowanie swego artykułu o Miškinie z okazji wizyty grupy pisarzy jugosłowiańskich w Polsce oraz rewizyty literatów polskich w Jugosławii ${ }^{60}$. Przesłał wtedy przekłady nowel Miškiny do „Trybuny Robotniczej” w Katowicach ${ }^{61}$, „Dziennika Zachodniego” w Katowicach oraz innych gazet i prosił o ich opublikowanie ${ }^{62}$. W grudniu dowiedział się, że „Wies" jednak zamieściła artykuł „Mihovil Pawlek-Miszkina, chorwacki chłop-literat”, prosił

${ }^{53}$ BUJ Kraków, SpWB - rkps 43/56, W. Bazielich - [Edmund Odorkiewicz, poseł KRN], Katowice 25 VI 1946.

54 BUJ Kraków, SpWB - rkps 43/56, W. Bazielich - Redakcja tygodnika „Odrodzenie”, Katowice 2 XI 1946.

${ }_{55}$ BUJ Kraków, SpWB - rkps 43/56, W. Bazielich - [J. Benešić, Zagrzeb], Katowice 6 II 1947.

56 BUJ Kraków, SpWB - rkps 43/56, W. Bazielich - Redakcja tygodnika „Wieś”, Katowice 3 VII 1946.

${ }^{57}$ BUJ Kraków, SpWB - rkps 43/56, W. Bazielich - Redakcja tygodnika „Wieś”, Katowice 6 VIII 1946.

${ }_{58}$ BUJ Kraków, SpWB - rkps 43/56, Redakcja tygodnika „Wieś” - W. Bazielich, Łódź 25 IX 1946.

${ }_{59}$ BUJ Kraków, SpWB - rkps 43/56, W. Bazielich - Redakcja tygodnika „Wieś”, Katowice 13 XII 1946.

${ }^{60}$ BUJ Kraków, SpWB - rkps 44/56, W. Bazielich - Redakcja tygodnika „Wieś”, Katowice 22 X 1947.

${ }^{61}$ BUJ Kraków, SpWB - rkps 44/56, W. Bazielich - Redakcja „Trybuny Robotniczej”, Katowice 23 X 1947.

${ }^{62}$ BUJ Kraków, SpWB - rkps 44/56, W. Bazielich - Redakcja „Dziennika Zachodniego”, Katowice 23 X 1947. 
więc, aby mu przesłali egzemplarz autorski tygodnika i honorarium ${ }^{63}$. Skarżył się Esihowi, że „musiał” zaopatrzyć aż siedem tygodników w materiały jugosłowiańskie, a tylko „Odra” poświęciła temu więcej miejsca oraz „Wieš", publikując jego artykuł o Miškinie. W liście do Esiha twierdził, iż przyjazd jugosłowiańskich literatów „nie był należycie przygotowany, ani na czas zapowiedziany" ${ }^{\prime \prime}$.

Ambasadzie Jugosławii w Warszawie Bazielich oferował swoją współpracę w tłumaczeniach i innych aktywnościach kulturalnych, a w zamian oczekiwał gazet, czasopism, książek i innych publikacji, które ułatwiliby mu jego literacką działalność. W lutym 1946 Bazielich dostał list od radcy ambasady Uroša Kraighera z prośbą o przesłanie krótkiej biografii i listy prac, szczególnie tych z dziedziny stosunków polsko-jugosłowiańskich ${ }^{65}$. Bazielich zaczął otrzymywać większą liczbę periodyków, w związku z czym w maju 1946 roku dziękował Kraigheru za przesłane czasopisma („Republika”, „Naša književnost”, „Radio-Beograd”, „Letopis Matice srpske” i dr.) i prosił, aby mu je dalej dostarczano, a w miarę możliwości i jakieś książki ${ }^{66}$. Jednak nie zawsze Bazielich był zadowolony z zaopatrzenia w jugosłowiańską prasę i czasopisma. Przykładowo, pod koniec 1946 roku był mocno rozczarowany, bo „ambasada już nawet gazet nie przesyła nam od przeszło dwóch miesięcy”. Oczekiwał poprawy sytuacji w związku z przyjazdem nowego ambasadora - może on „wprowadzi jakie lepsze stosunki i zwyczaje"67.

Impulsem, który spowodował zainteresowanie Bazielicha tłumaczeniem dziennika Vladimira Nazora S partizanima 1943-1944, był Jerzy Pogonowski, a właściwie jedna jego notatka o tym dziele: „Bardzo chętnie przetłumaczyłbym tę rzecz, zwłaszcza że mam już za sobą parę drukowanych przekładów tegoż autora” - pisał do Pogonowskie$\mathrm{go}^{68}$. Jednak na prośbę Bazielicha, aby mu wypożyczył książkę Nazora w celu przekładu, Pogonowski odpowiedział, że książka nie należy do niego. Ostatecznie Bazielich dostał książkę na krótko od Vilima Frančicia, lektora języka serbsko-chorwackiego na Uniwersytecie Jagiellońskim ${ }^{69}$.

Dlatego Bazielich dalej starał się o książkę Vladimira Nazora, rozpytywał się o nią w ambasadzie u attaché Kusovca, podkreślając, że on już „przed wojną tłumaczył go na polski i właśnie dlatego, ale i w związku z aktualnością tematu, który opisuje”, chętnie by przetłumaczył tę książkę, gdyż uważa, że natrafiłaby na dobre przyjęcie

${ }^{63}$ BUJ Kraków, SpWB - rkps 44/56, W. Bazielich - Redakcja tygodnika „Wieś”, Katowice 1 XII 1947.

${ }^{64}$ BUJ Kraków, SpWB - rkps 44/56, W. Bazielich - Ivan Esih, Katowice 1 XII 1947.

${ }^{65}$ BUJ Kraków, SpWB - rkps 43/56, Ambasada Demokratske Federativne Jugoslavije - W. Bazielich, Varšava 13 februara 1946.

${ }^{66}$ BUJ Kraków, SpWB - rkps 43/56, W. Bazielich - [Uroš Kraigher, Ambasada Demokratske Federativne Jugoslavije], Katowice 9 V 1946.

${ }^{67}$ BUJ Kraków, SpWB - rkps 43/56, W. Bazielich - [Jakub Kołodziej, Warszawa], Katowice 31 XII 1946.

${ }^{68}$ BUJ Kraków, SpWB - rkps 43/56, W. Bazielich - [Dr Jerzy Pogonowski, Kraków], Katowice 9 XII 1945.

${ }^{69}$ BUJ Kraków, SpWB - rkps 43/56, Jerzy Pogonowski - W. Bazielich, Kraków 15 XII 1945. 
$(?)^{70}$. Wysiłki uwieńczone zostały sukcesem. Już kilka dni później otrzymał dzieło Nazora i od razu je przeczytał „z wielkim zainteresowaniem”, szczególnie dlatego, że o jego przejściu w szeregi partyzantów czytał już w czasie wojny w jakiejś sarajewskiej gazecie, która przypadkiem trafiła do jego rąk w Krakowie: „Dziwiłem się wtedy staremu poecie, a dziś dziwię się jeszcze bardziej, jak mógł wytrzymać te wszystkie trudności partyzanckiego życia"71. Otrzymawszy książkę i przeczytawszy ją, Bazielich ocenił, że przekład nie będzie łatwy „z powodu licznych skrótów” (sic).

Dwa miesiące później, pod koniec lutego 1946, Bazielich pisał do pani Sobierajskiej w Towarzystwie Przyjaźni Polsko-Jugosłowiańskiej w Warszawie i zgłosił gotowość rozpoczęcia tłumaczenia dziennika Nazora, ale „tylko na wyraźne pisemne zamówienie, gdyż w danym razie musiałbym odłożyć inne moje prace”. Przypuszczał, że pracę tę rozpocząć może w najbliższych dniach - „biorąc jednak pod uwagę, że dla czytelnika polskiego trzeba by dodać pewne objaśnienia tekstu, liczę, że gotowy maszynopis mógłbym dostarczyć nie wcześniej jak za 3-3 $3^{1 / 2}$ miesięcy". W związku z tym, że "nazwisko Nazora mało jest u nas znane”, Bazielich uważał, że potrzebna jest przedmowa do wydania polskiego, w której byłaby przedstawiona jego twórczość oraz znaczenie polityczne. $\mathrm{W}$ tej sprawie proponował, aby wstęp napisał Vilim Frančić, ale podkreślał też, że trzeba porozumieć się z ludźmi z ambasady jugosłowiańskiej z Warszawy, bo właśnie z tej strony nadeszła inicjatywa tłumaczenia książki. Pytał też o ewentualnie podanie wysokości honorarium za tłumaczenie oraz obiecywał przesłać spis swoich jeszcze niepublikowanych przekładów (z literatury jugosłowiańskiej) $)^{72}$.

Pod koniec lipca 1946 Bazielich informował Kusovca o postępach w tłumaczeniu książki V. Nazora (miał już przetłumaczonych około 90 stron), tego „Wielkiego Poety Chorwacji” („Veliki Pjesnik Hrvatske”) oraz „nestora pisarzy jugosłowiańskich”, jak go nazywał. Usprawiedliwiał się za odkładanie terminu zakończenia swej pracy: „cały przekład byłby już dawno gotowy, gdyby nie dość częste w ostatnich miesiącach moje wyjazdy służbowe i kilka innych prac, które mi dużo czasu zabierają" ${ }^{\prime 3}$. Jednym z zajęć, które przeszkadzało mu w tłumaczeniu Nazora, było rozszerzenie jego odczytu o polsko-jugosłowiańskich stosunkach politycznych. Dużo pracował nad źródłami, pamiętnikami, monografiami historycznymi: „do polskich nie zawsze można dziś dotrzeć, a jugosłowiańskie są mi zupełnie niedostępne”.

Pracując nad przekładem, Bazielich napisał też jeden artykuł o Nazorze poświęcony jego jubileuszowi (Nazor w 1946 roku ukończył 70 lat). W sierpniu 1946 przesłał tekst

${ }^{70}$ BUJ Kraków, SpWB - rkps 43/56, W. Bazielich - [L. Kusovac, Warszawa], Katowice 11 XII 1945.

${ }^{71}$ BUJ Kraków, SpWB - rkps 43/56, W. Bazielich - [L. Kusovac, Warszawa], Katowice 30 XII 1945.

72 BUJ Kraków, SpWB - rkps 43/56, W. Bazielich - p. Mgr. Sobierajskiej, Warszawa, Katowice 28 II 1946.

${ }^{73}$ BUJ Kraków, SpWB - rkps 43/56, W. Bazielich - [L. Kusovac, Warszawa], Katowice 26 VII 1946. 
do czasopisma „Odra” z prośbą o opublikowanie („jeśli się nie nada, proszę wyrzucić w kosz, a jeśli się nada, proszę o dwa egzemplarze autorskie") ${ }^{74}$. Artykuł został wydany, bo pod koniec sierpnia Bazielich informował Kusovca o tym z prośbą o przesłanie Nazorowi jednego egzemplarzu tekstu oraz pozdrowien ${ }^{75}$. Kusovac zrobił to - przesłał artykuł pocztą dyplomatyczną.

Jesienią 1946 Bazielich kończył pracę nad przekładem dziennika Vladimira Nazora. $Z$ jednej strony, już przez dłuższy czas nad tym pracował, a z drugiej, ponaglano go $\mathrm{z}$ ambasady w Warszawie. Kusovac rozmawiał z nim o tym na posiedzeniu Komitetu Towarzystwa Polsko-Jugosłowiańskiego w Warszawie, a potem pospieszał go i - pisemnie - twierdził, że jest w trakcie rozmów o wydaniu książki w jednym polskim wydawnictwie ${ }^{76}$.

Tekst tłumaczenia Bazielicha był napisany ręcznie, a nie przepisany na maszynie, jak chciał Kusovac - bo na przepisanie tłumacz nie miał „ani czasu, ani pieniędzy”. W ogóle Bazielich usprawiedliwiał się, że był „straszliwie zarzucony najrozmaitszymi pracami dla codziennego chleba, troskami i kłopotami", a z drugiej strony, dużo czasu potrzebował do opracowania wyjaśnień tekstu Nazora w przypisach. Od ambasady Bazielich oczekiwał przynajmniej na „jakąś zaliczkę na poczet honorarium"77.

Najwyraźniej z ambasady sugerowano mu, że należałoby złożyć tekst przepisany na maszynie do pisania. To zrobił i kilka tygodni później mógł go przesłać do attaché Kusovca, żałując, że nie mógł tego przekazać osobiście, gdy z początkiem grudnia był na delegacji w Warszawie w Ministerstwie Komunikacji ${ }^{78}$. Maszynopis tłumaczenia Bazielich przeglądał dokładnie i zaznaczył na marginesie poprawki: „Stylistycznych czy językowych błędów znalazłem bardzo mało. Olbrzymia większość to błędy pochodzące z błędnego odczytania rękopisu przez osobę, która przepisywała, a która - jak widzę - nie zna języka serbsko-chorwackiego i nie ma pojęcia o nazwach i nazwiskach jugosłowiańskich".

Oddając tłumaczenie dziennika Nazora, Bazielich prosił Kusovca, aby mu pozwolić osobiście przeprowadzić korektę, przynajmniej ostateczną: „w książce jest mnóstwo nazwisk, imion i nazw jugosłowiańskich, z którymi - niestety - ani czytelnicy polscy, nawet o wysokim wykształczeniu, ani drukarze nie są obeznani..." ${ }^{79}$

Miesiąc później pytał swego jugosłowiańskiego korespondenta, czy z książką Nazora coś się dzieje - „czy drukuje się już, a w danym razie, kto to wydaje?”" Najwyraźniej jeszcze wtedy żył w przekonaniu, że jugosłowiańska ambasada postara się o wydanie

${ }^{74}$ BUJ Kraków, SpWB - rkps 43/56, W. Bazielich - [Redakcja „Odry”], Katowice 6 VIII 1946.

75 BUJ Kraków, SpWB - rkps 43/56, W. Bazielich - [L. Kusovac, Warszawa], Katowice 29 VIII 1946.

${ }^{76}$ BUJ Kraków, SpWB - rkps 43/56, [L. Kusovac] - Wiktor Bazielich, Warszawa 23 X 1946.

77 BUJ Kraków, SpWB - rkps 43/56, W. Bazielich - [L. Kusovac, Warszawa], Katowice 26 X 1946.

${ }_{78}$ BUJ Kraków, SpWB - rkps 43/56, W. Bazielich - [L. Kusovac, Warszawa], Katowice 10 XII 1946.

79 BUJ Kraków, SpWB - rkps 43/56, W. Bazielich - [L. Kusovac, Warszawa], Katowice 10 XII 1946.

${ }^{80}$ BUJ Kraków, SpWB - rkps 43/56, W. Bazielich - [L. Kusovac, Warszawa], Katowice 12 I 1947. 
dziennika Vladimira Nazora. Pisał do Kusovca i na początku marca 1947 roku, pytając go, co nowego z jego tłumaczeniem, czy maszynopis oddany jest do druku, kto będzie wydawcą oraz czy będą jakieś ilustracje. Pytał też, czy może dostać „jakąś zaliczkę" na poczet honorarium za tłumaczenie („bo jestem naprawdę w wielkiej potrzebie”) ${ }^{81}$. Odpowiedzi na ten list w korespondencji Bazielicha nie znalazłem. Kusovac najwyraźniej wyjechał z powrotem do Belgradu, a na jego miejsce - attaché zajmującego się informacją i kulturą - przyjechał Radomir Šaranović.

W związku z tym Bazielich na początku kwietnia 1947 roku zwrócił się do ambasady z pytaniem i otrzymał oficjalną odpowiedź, którą na polecenie ambasadora podpisał attaché Ratko Pešić. W liście tym podane są warunki, jakie zaoferowała Zavod za autorsko-pravno posredništvo - instytucja zajmująca się pośrednictwem $\mathrm{w}$ sprawie praw autorskich z Belgradu. Zgodnie z tymi warunkami dziennik V. Nazora mógł być opublikowany po polsku za honorarium autorskie w wysokości 10\% ceny książki, przy czym honorarium miało być wypłacone po ukazaniu się tytułu, a autor miał otrzymać 15 egzemplarzy autorskich ${ }^{82}$.

W lipcu 1947 roku Bazielich od attaché Šaranovicia dostał krótki list następującej treści: „Zostaliśmy poinformowani, że Pan przetłumaczył na język polski dziennik 'S partizanima' Vladimira Nazora. Ponieważ w celu publikacji dzieła potrzebna jest zgoda autora na tłumaczenie, jak również umowa w sprawie druku książki, proszę nas poinformować, jak się sprawy mają z tym tłumaczeniem, jak również, czy i kiedy ma Pan zamiar opublikować dzieło"83. Tydzień później, 18 lipca 1947 roku Bazielich odpowiada obszernie: „pośpieszam wyjaśnić i przypomnieć, że przekładu dokonałem z inicjatywy i na propozycję Ambasady w osobie dra Kusovca, z którym przeprowadziłem w tej sprawie wiele rozmów i korespondencji”; nawet $\mathrm{z}$ jednego $\mathrm{z}$ listów Kusovca wynikało, że znalazł on wydawcę („co mi też zresztą później potwierdził także i ustnie, oświadczając, że sprawę wydania Ambasada bierze na siebie"). Po oddaniu przekładu, Bazielich przez dłuższy czas nie miał kontaktów z Kusovcem, a dopiero w kwietniu dowiedział się o przeniesieniu Kusovca z Warszawy i wtedy to poinformowano go w Ambasadzie ustnie o tym, że sam ma poszukać polskiego wydawcę: „Nawiązałem więc korespondencję ze Spółdzielnią Wydawniczą 'Książka' i na jej życzenie, ponieważ zainteresowała się tą książką, przesłałem jej maszynopis dnia 28 VI br." Jednocześnie pod koniec czerwca Bazielich napisał list do Ambasady, prosząc o adres Zavoda za autorsko-pravno posredništvo w Belgradzie. Sam Bazielich, oczywiście, bardzo pragnął, aby książka ukazała się jak najprędzej („choćby z uwagi na moje honorarium tłumacza"), ale nie miał na to wpływu - szczególnie martwiła go wysokość honorarium żądana przez autora: $10 \%$ - „przez to mam pewne obawy,

${ }^{81}$ BUJ Kraków, SpWB - rkps 43/56, W. Bazielich - [L. Kusovac, Warszawa], Katowice 3 III 1947.

82 BUJ Kraków, SpWB - rkps 43/56, [Ratko Pešić, Ambasada FNR Jugosławii, Warszawa] - W. Bazielich, Warszawa 4 IV 1947.

${ }_{83}$ BUJ Kraków, SpWB - rkps 43/56, [Radomir Šaranović, Ambasada FNR Jugosławii, Warszawa] W. Bazielich, Warszawa 11 VII 1947. 
czy naszym nakładcom nie wyda się to za dużo”. Deklarował też, że poszuka innego wydawcę, jeśli „Książka” odmówi ${ }^{84}$.

Tak więc, w czerwcu 1947 roku Bazielich sam zaczął poszukiwać polskiego wydawnictwa, które byłoby zainteresowane opublikowaniem dziennika Vladimira Nazora. Na początku czerwca zwrócił się do „Książki” i krótko wyjaśnił, co proponuje: pamiętnik Vladimira Nazora, którego opisuje jako „najwybitniejszy poeta i prozaik chorwacki, nestor literatów jugosłowiańskich". Bazielich mylnie nazywa go „szefem” Ludowej Republiki Chorwackiej, gdyż Nazor nie był głową państwa ani główną osobą w komunistycznej Chorwacji po wojnie, ale „tylko” przewodniczącym parlamentu - Sabora NR Hrvatske ${ }^{85}$. Wkrótce Bazielich dostał pozytywną odpowiedź od wydawnictwa warszawskiego ${ }^{86}$. Nareszcie miał wydawcę dla swojego przekładu. Pod koniec czerwca przesłał do Warszawy maszynopis książki ${ }^{87}$, a we wrześniu miał jechać do Warszawy, aby podpisać umowę ${ }^{88}$. Nastąpiło to 15 września, a już dwa tygodnie później prosił o szybkie przesłanie zaliczki w wysokości $25 \%$ honorarium, bo "gotówki pilno potrzebuję na zapłacenie pierwszej raty za meble poniemieckie" ${ }^{9}$. Kilka miesięcy później Bazielich wciąż nie dostał kopii podpisanej umowy, nie było też wiadomo, kiedy książka ukaże się drukiem. O to pytał wydawnictwo, podkreślając, że chce o tym poinformować Ambasadę Jugosłowiańską i samego autora, który „także zapytuje mnie o tym". Nie znalazłem listu Vladimira Nazora w spuściźnie - możliwe, że Bazielich napisał to tylko po to, aby wywrzeć dodatkowy nacisk na wydawcę. Pisał też: „Przy sposobności komunikuję, że jeśli inne wydawnictwa 'Książki' nie zdystansują, będzie to pierwsza po wojnie książka jugosłowiańska wydana w Polsce, nadto że czeski jej przekład wyszedł już przed rokiem"90. Czy ten list przyspieszył sprawę w Warszawie, czy też nie, trudno powiedzieć, ale już po tygodniu Bazielich dostał kartkę pocztową z informacją, iż korektę szpaltową dostanie w lutym i aby wtedy jak najszybciej ją zwrócił ${ }^{91}$.

${ }^{84}$ BUJ Kraków, SpWB - rkps 43/56, W. Bazielich - [Ambasada FNR Jugosławii, Warszawa], Katowice 18 VII 1947.

${ }^{85}$ BUJ Kraków, SpWB - rkps 43/56, W. Bazielich - Spółdzielnia Wydawnicza Książka, Katowice 7 VI 1947.

${ }^{86}$ BUJ Kraków, SpWB - rkps 43/56, [S. Kłonowski, SP „Książka, Warszawa] - W. Bazielich, Warszawa 18 VI 1947.

${ }^{87}$ BUJ Kraków, SpWB - rkps 43/56, W. Bazielich - Spółdzielnia Wydawnicza Książka, Katowice 28 VI 1947.

${ }^{88}$ BUJ Kraków, SpWB - rkps 43/56, Spółdzielnia Wydawnicza Książka - W. Bazielich, Warszawa 1 IX 1947. BUJ Kraków, SpWB - rkps 43/56, W. Bazielich - Spółdzielnia Wydawnicza Książka, Katowice 3 IX 1947.

${ }^{89}$ BUJ Kraków, SpWB - rkps 43/56, W. Bazielich - Spółdzielnia Wydawnicza Książka, Katowice 1 X 1947.

90 BUJ Kraków, SpWB - rkps 44/56, W. Bazielich - Spółdzielnia Wydawnicza Książka, Katowice 20 I 1948.

${ }_{91}$ BUJ Kraków, SpWB - rkps 44/56, Spółdzielnia Wydawnicza Książka - W. Bazielich, Warszawa 28 I 1948. 
Niewątpliwie z niecierpliwością czekał na rezultat swej długoletniej pracy i wysiłków. W kwietniu 1948 dostał list z Warszawy, w którym informują go, że książka V. Nazora oddana została do składu, ale z wydawnictwa ostrzegali: „Mamy jednak dużo zastrzeżeń co do pisowni oraz znaczenia pewnych wyrażeń, które należy porównać z oryginałem"92. W liście tym zapisane są wszystkie wątpliwości, a Bazielich został poproszony, aby jak najszybciej zrobił korektę. I choć mowa jest o wielu zastrzeżeniach, wymieniono tylko około 15 i nie wydały się one zbyt poważne. Bazielich już po tygodniu odpowiedział i odesłał korektę. Był zadowolony: „Cieszę się, że nareszcie książka się drukuje, a proszę korektę przysłać mi jak najprędzej, gdyż mnóstwo mam roboty przed sobą"93.

Na początku maja Bazielich z łódzkiego zarządu wydawnictwa „Książka” dostał skład Walki z partyzantami, polskie tłumaczenie i chorwacki oryginał z prośbą, aby przetłumaczył podpisy pod ilustracjami ${ }^{94}$. Bazielich przeprowadził korektę, zaznaczył i podał tytuły poszczególnych rozdziałów, przygotował podpisy pod ilustracjami i znowu poprosił, aby usunięto rozdział „Podziemna Bośnia”, ponieważ życzył sobie tego sam Nazor. Jego główne zastrzeżenie dotyczyło tytułu książki - nie Walka z partyzantami - jak było napisane w szpaltach i w liście z 7 maja 1948 - ale $Z$ partyzantami ${ }^{95}$. Z jego strony książka była gotowa i mógł tylko czekać z niecierpliwością na swoje egzemplarze autorskie. W liście do Referatu Kulturalno-Prasowego Ambasady Jugosłowiańskiej w Warszawie w połowie czerwca pisał, że książka jest $\mathrm{w}$ druku. Pragnąc prawdopodobnie podkreślić swe zasługi, Bazielich pisał, iż wydaje mu się, „że będzie to pierwsza po wojnie jugosłowiańska książka wydana w Polsce" ${ }^{\text {" }}$. $\mathrm{Ku}$ jego wielkiemu niezadowoleniu książka nie ukazała się jednak w ciągu lata 1948 roku, a oczekiwane honorarium nie nadeszło. Właśnie w czasie, gdy przeprowadzał korektę szpalt i radośnie informował Ambasadę Jugosłowiańską o postępach i o tym, że książka jest już w druku, konflikt pomiędzy kierownictwem politycznym Jugosławii na czele z Josipem Brozem Titą i władzami Związku Sowieckiego oraz Kominformem dosięgał zenitu - doszło do Rezolucji Kominformu wykluczającej Jugosłowiańską Partię Komunistyczną z tej struktury i w konsekwencji do zerwania wzajemnych stosunków pomiędzy Jugosławią i państwami bloku sowieckiego. Okoliczności publikacji dziennika Vladimira Nazora, jednego z członków najwyższych władz jugosłowiańskich, zmieniły się w zupełności. Nie było już mile widziane drukowanie książek autorów jugosłowiańskich, a w szczególności książki o takiej tematyce. Bazielich najwyraźniej

92 BUJ Kraków, SpWB - rkps 44/56, Spółdzielnia Wydawnicza Książka - W. Bazielich, Warszawa 10 IV 1948.

${ }_{93}$ BUJ Kraków, SpWB - rkps 44/56, W. Bazielich - Spółdzielnia Wydawnicza Książka, Katowice 18 IV 1948.

${ }_{94}$ BUJ Kraków, SpWB - rkps 44/56, Spółdzielnia Wydawnicza Książka - W. Bazielich, Łódź 7 V 1948.

${ }_{95}$ BUJ Kraków, SpWB - rkps 44/56, W. Bazielich - Spółdzielnia Wydawnicza Książka, Katowice $18 \mathrm{~V} 1948$.

96 BUJ Kraków, SpWB - rkps 44/56, W. Bazielich - Referat kulturalno-prasowy Ambasady jugosłowiańskiej, Katowice 13 VI 1948. 
był tego świadom, więc w połowie września 1948 roku pisał do zarządu wydawnictwa „Książka”. Powołując się na konwencję zawartą przez Związek Zawodowy Literatów Polskich, którego był członkiem, z Polskim Towarzystwem Wydawców Książek 25 maja 1947, prosił o wypłacenie reszty honorarium (36000 złotych): „Nie ma więc po mojej stronie żadnej zwłoki i nie z mojej winy wydanie książki tak długo się przeciąga”. Oczekiwał swojego honorarium w ciągu dwóch tygodni ${ }^{97}$. Tego samego dnia zwrócił się z innym krótkim listem do wydawnictwa „Książka” i prosił o odpowiedź, co z jego tłumaczeniem powieści Hamzy Huma Chichot Grozdany.

Jesienią było już zupełnie jasne, że projekt upadł. W jednym $\mathrm{z}$ listów do Julija Benešicia Bazielich pisał, że „na pewno nie wyjdzie” jego przekład książki Nazora $S$ partizanima. Skarżył się też, opisując sytuację w Polsce w związku ze stosunkiem do Jugosławii, „Obecnie bardzo rzadko i bardzo mało pisze się u nas o Was i tylko niemal wyłącznie o sprawach politycznych. Sprawy z zakresu kultury i sztuki pozostawiono zupełnie odłogiem" ${ }^{\prime \prime}$.

Sam Bazielich w ciągu lata i jesieni 1948 roku napisał kilka listów do swoich chorwackich przyjaciól, podkreślając, jak bardzo nieszczęśliwy jest w związku z zaistniałą sytuacją. Według informacji w Encyklopedii Sądeckiej, a w zasadzie w zupełności zgodnie z tym, co można było przypuszczać, Bazielich stał się przedmiotem śledztwa tajnej policji politycznej z powodu swoich szerokich kontaktów z osobami z Jugosławiii" Być może, archiwa polskich tajnych służb kryją dokumenty tego śledztwa.

Bazielich nie miał wielkiego talentu literackiego, ale był niezwykle pracowity i wytrwały w swych wysiłkach. Niełatwo było go zniechęcić odmowami, które często dostawał od redakcji szanowanych czasopism. Jeśli nie udało się w jednym miejscu, swoje teksty przesyłał do innych wydawców aż przezwyciężył ich opór. Czasami nie miał umiaru w pytaniu o los swoich tekstów, o to, czy będą opublikowane, a przy tym powoływał się na swoją osobistą umowę z autorami lub na to, że tłumaczenie powstało z inicjatywy Ambasady Jugosłowiańskiej. Nie zniechęcał się negatywnymi uwagami, jak te otrzymane od redakcji „Odrodzenia” z Krakowa, która napisała, że tekst jest „stylistyczne nieświtne, również w tłumaczeniach” i sugerowała, aby zwrócił uwagę na formę ujęcia ${ }^{100}$.

${ }_{97}$ BUJ Kraków, SpWB - rkps 44/56, W. Bazielich - Spółdzielnia Wydawnicza Książka, Katowice 18 IX 1948.

${ }_{98}$ BUJ Kraków, SpWB - rkps 44/56, W. Bazielich - J. Benešić, Katowice 7 XI 1948.

99 J. Leśniak - A. Leśniak, Encyklopedia sądecka, Urząd Miejski w Nowym Sączu, Nowy Sącz 2000. Biogram Wiktora Bazielicha.

${ }^{100}$ BUJ Kraków, SpWB - rkps 43/56, [Redakcja tygodnika „Odrodzenie”] - W. Bazielich, Kraków 24 IX 1946. 
Chociaż Bazielich z pewnością nie był wybitnym, a raczej nawet dość kiepskim tłumaczem, o czym świadczą przedwojenne zapiski Julije Benešicia ${ }^{101}$, to jednak znaczenie całej jego pracy na promocji chorwackiej i serbskiej kultury w Polsce w okresie międzywojennym i bezpośrednio po II wojnie światowej nie jest sporne. Jego spuścizna jest niewątpliwie również ważna jako źródło do badań nad historią chorwacko-polskich i serbsko-polskich stosunków kulturalnych. Widoczne są w niej nie tylko konkretne wysiłki jednej osoby na rzecz promocji literatury chorwackiej i serbskiej w Polsce, szczególnie jej sukcesy i porażki, lecz także cały kontekst tych stosunków, a nawet to, że chorwaccy i serbscy literaci i naukowcy chętnie czytali po polsku, śledzili polską produkcję kulturalną i pragnęli być obecni na tej scenie.

Wytrwałe prośby Bazielicha skierowane do Ambasady Jugosłowiańskiej w Warszawie o to, aby przesyłano mu czasopisma literackie i inne wydania, w tym książkowe, świadczą być może również o pewnej indolencji jugosłowiańskiej dyplomacji na polu kultury. Słabości organizacyjne tejże dyplomacji potwierdza również fakt, że w pierwszych latach powojennych, po konflikcie z roku 1948 i później, w Polsce nie została wydana ani jedna książka autora z Jugosławii. W tym samym czasie w samej Chorwacji opublikowano kilka przekładów literatury polskiej, np.: Lalka B. Prusa (1946), Opowieści S. Żeromskiego (1947), Popiót i diament J. Andrzejewskiego (1949) ${ }^{102}$. W 1948 roku Towarzystwo Przyjaźni Chorwacko-Polskiej (Hrvatsko-poljsko društvo prijateljstva) wydało obszerny tom Današnja Poljska (Dzisiejsza Polska). Oczywiście, po zerwaniu stosunków w 1948 roku tego typu aktywności słabną. Możliwym wyjaśnieniem tej dysproporcji jest obecność na chorwackiej scenie kulturalnej - obok innych miłośników Polski - Julija Benešića i jego pozycja, która była niewątpliwie bardziej znacząca i wpływowa od pozycji Wiktora Bazielicha.

101 J. Benešić, Osam godina u Varšavi, RAD JAZU, knj. 390, s. 317 i dr.

102 T. Šarić, Kulturna politika vlasti u NR Hrvatskoj - primjer Matice hrvatske 1945.-1952., Magistarski rad, Zagreb 2008, s. 146-147. 